\title{
DISCRETIONARY POWER IN THE JUDICTARY TO ORGANIZE A SPECLAL INVESTIGATING GRAND JURY
}

After extensive investigation of the relationship between organized crime and government, the Kefauver Committee reported in 1951 that much corruption, because of its local character, was beyond the control of Congress, and that more effective local law enforcement was necessary. ${ }^{1}$ Ultimately, effective law enforcement depends upon the control over public officials exercised by the electorate. As the functions of government expand into areas formerly considered matters of individual concern, it becomes increasingly important that irresponsible action be checked. However, citizen control can only be effective if there is an adequate store of information available to support an enlightened judgment of the performance of public officials. And yet, government today "has taken on a complexity of organization and of operation that defies the best intentions of the citizen to know and understand it." 2 This complexity is aggravated by the growing number of appointed government employees whose official acts are not subject to periodic review by the electorate. ${ }^{3}$ Furthermore, the existence of the so-called "political machine" with its independent structure of personal loyalties impedes the exposure of reprehensible conduct. Clearly, there exists a great potential for the misuse of public office when government functions beyond the gaze of an informed citizenry. ${ }^{4}$

Traditionally, the task of checking the conduct of public officials has fallen largely to the grand jury, which, because of its unique investigatory powers, is particularly well equipped to determine the existence of governmental corruption. ${ }^{5}$ The grand jury can subpoena unwilling witnesses,

1 S. REP. No. 307, $82 d$ Cong., 1st Sess. 5 (1951). See King, The Control of Organized Crime in America, 4 STAN. L. REv. 52 (1951), criticizing the committee's conclusion that the federal government could not control such corruption.

2 In the Matter of the Presentment by Camden County Grand Jury, 10 N.J. 23, 65, 89 A.2d 416, 443 (1952).

${ }^{3}$ See Kuh, The Grand Jury "Presentment": Fonl Blow or Fair Play?, 55 Colum. L. REV. 1103, 1118 (1955). This is not only true in the case of party workers rewarded for their loyalty with public appointments, but applies to civil service appointees whose trustworthiness or competence also cannot be appraised by the electorate.

4 It has been argued that the role of supplying information is filled today by newspapers and that therefore there is no need for investigating grand juries. See Cook, New York Troika: Conflicting Roles of the Grand Jury, 11 BuFr. L. REv. 42, 53 (1961); Scragg, The Grand Jury, 2 Temp. L.Q. 317, 318 (1928). Newspapers undoubtedly do expose areas where investigations are needed. But newspaper reports of corruption, if unsubstantiated by official investigation, are hardly a sound basis for exercising control via the ballot; too often they are open to the charge that they are a product of either "politics" or sensationalism designed to increase circulation.

6 See Wirloughby, Principles of Judicial Administration 193-94 (1929); Dession \& Cohen, The Inquisitorial Functions of Grand Juries, 41 YALE I.J. 687, $694-700$ (1932); Konowitz, The Grand Jury as an Investigating Body of Public Officials, 10 St. JoHN's L. Rev. 219, 235 (1936); Nahum \& Schatz, The Grand Jury 
cite for contempt, and grant immunity from prosecution. ${ }^{6}$ Aside from its special powers, the grand jury's impressive stature derives from the public's belief that its investigations are politically impartial and independent of the executive and legislature. This belief results no doubt from the identification in the public mind of the grand jury with the judiciary, ${ }^{7}$ although in fact its powers of investigation and accusation are essentially executive. ${ }^{8}$ It is significant that nearly all of the various investigatory bodies authorized to delve into local corruption in the United States have been in some fashion related to the judiciary ${ }^{8}$ and that all states provide for grand juries even though in many the indictment has given way to the prosecutor's information..$^{10}$ Even commentators who advocated abolition of the grand jury indictment during the first thirty years of the century conceded that grand juries should be retained as investigating bodies. ${ }^{11}$

Unlike the grand jury, the local district attorney is hampered in the conduct of an investigation by his lack of power in most jurisdictions to subpoena witnesses, as well as by his inability to grant immunity from

in Connecticut, 5 CoNN. B.J. 111, 121 (1931). Virtually all of these authorities agree that the grand jury is not being fully utilized, generally because of the control exerted over it by the local prosecuting attorney. See also MAYers, Tre AMrerican LEGAL SySTEM 125-27 (1955).

${ }^{6}$ See Dession \& Cohen, supra note 5 , at 689-98; Konowitz, supra note 5 , at 235; Scigliano, The Grand Jury, the Information, and the Judicial Inquiry, 38 ORE. L. REv. 303, 308-09 (1959).

7 See EDwards, The Grand JuRy 40-41 (1906); Kaufman, The Grand JuryIts Role and Its Powers, 17 F.R.D. 331, 334 (1955); Note, The Grand Jury as an Investigatory Body, 74 HARV. L. REv. 590, 603-04 (1961).

8 See McCarthy v. Clancy, 110 Conn. 482, 495-96, 148 Atl. 551, 557 (1930); In re Application of Clark, 65 Conn. 17, 33, 31 Atl. 522, 52425 (1894). See generally WIILOUGHBY, op. cit. supra note 5, at 174 n.1; Winters, The Michigan One-Man Grand Jury, 28 J. AMr. Jud. Soc'y 137, 145-47 (1945); 38 Colvur. L. REv. 1493, 1500 (1938). Insofar as a grand jury makes decisions as to the sufficiency of evidence, it exercises what has generally been considered a judicial function. See Enwards, op. cit. supra note 7 , at 39 .

- Statutory variations from the ordinary grand jury exist in Michigan, Georgia, and California. Michigan authorizes a judge to appoint himself "a one-man grand jury," armed with all of the grand jury's investigatory weapons, and allows him to employ a staff for assistance MTCH. STAT. ANN. \$\$28.943-.945 (1954); see In re Investigation of Recount, 270 Mich. 328, 258 N.W. 776 (1935). See generally Scigliano, supra note 6, at 307-11; Winters, supra note 8; Marsh, Michigan's "One Man Grand Jury,' 8 J. AMc. JuD. Soc'y 121 (1924). Georgia and California provide for "auditing" grand juries; these are "regular" grand juries organized once each year with special powers to audit the records and books of all officials within each county. They too may employ accountants to assist them. CAx. PEN. CoDE $\$ \S 901$, 914.1, 919, 925, 926; GA. CODE ANN. $\$ \$ 59-309$ to -311 (1935). See generally Chamberiain, Auditing Grand Jury System Already Functioning in California and Forestalls Legislative Investigations, 12 The PaNed 6 (1934); Cumming, Georgia Grand Juries Check on Public Officials and Funds, 11 THE PANEL 1 (1933).

10 A majority of states now use the information system. See Morse, A Survey of the Grand Jury System, 10 ORE. L. REv. 101, 123 (1931).

11 To-day the grand jury is useful only as a general investigating body for inquiring into the conduct of public officers and in case of large conspiracies. It should be retained as an occasional instrument for such purposes, and the requirement of it as a necessary basis of all prosecutions for infamous crimes should be done away with.

U.S. National Comm'n on Law Obserfance and Enforcement, Report on Prosecution 37; see, e.g., WIILOUGHBX, op. cit. supra note 10, at 364-65; Editorial, The Grand Jury, A Venerable Nuisance, 8 J. Ax. Jun. Soc'y 99, 100 (1924). But see Cook, supra note 4, at 52-53; Scragg, supra note 4, at 318-19. 
prosecution and to initiate contempt proceedings. ${ }^{12}$ Moreover, he may fail to investigate allegations of corruption for political reasons. Although he himself may be untainted, still he may be "sensitive to the delicacy" of investigating persons upon whom he is dependent for electoral support. ${ }^{13}$

Investigations by legislative committees are subject to constant attack for lack of jurisdiction to make inquiry and are often stalled by the "materiality" defense to questions posed. ${ }^{14}$ In addition, corruption which may be of great local importance may not sufficiently interest the state legislature. ${ }^{15}$ If the legislature does proceed to investigate, its decision may be politically motivated, and even if it is not, the investigation may have political overtones, at least in the public mind.

To prevent the politically motivated investigation and to reduce expenses, ${ }^{16}$ Michigan has statutorily authorized its judges to appoint themselves as one-man grand juries to investigate charges of widespread crime and corruption. ${ }^{17}$ This system has proved effective, ${ }^{18}$ but it may be undesirable to have a judge act as an investigator. Even while exercising what are essentially prosecutorial powers, a judge remains a judge, and to the extent that he becomes involved in uncovering political corruption, there is danger that the prestige of the judiciary, particularly its reputation for political impartiality, may be impaired..$^{19}$ Indeed, there may be a suspicion that the judge is using his power to further his own political career. ${ }^{20}$ In

12 See Dession \& Cohen, supra note 5 , at 691.

13 Scigliano, supra note 6, at 309-10. See generally Appleton, Special Counsel for Grand Juries, 8 THE PANEL 1 (No. 5, 1930); Vukasin, The Grand Jury-Useful or Useless?, 34 CAL. B.J. 436, 443 (1959); Note, supra note 7, at 603-04.

14 See generally Dession \& Cohen, supra note 5, at 699-700; Note, supra note 7, at $603-04$

$15 \mathrm{Id}$. at 603.

16 See Marsh, supra note 9, at 123; Scigliano, supra note 6, at 311 ; Winters, supra note 8 , at 143 .

17 Mich. Stat. Ann. $\$ 28.943$ (1954). These one-man grand juries have generally been called to investigate charges of political scandal. See Marsh, supra note 9 , at 121; Scigliano, supra note 6 , at 307.

18 See Marsh, supra note 9, at 123.

19 The "one-man grand jury" has been severely criticized on this ground. See Gallagher, The One-Man Grand Jury-A Reply, 29 J. AM. Jud. Soc'y 20 (1945); Scigliano, supra note 6, at 313-14; Winters, supra note 8, at 145-46, 148; Note, supra note 7 , at $604-05$. Gallagher also argues that the presumption of innocence is virtually nullified because the indictment is returned by a judge. No adequate answer has been given to this contention. Since the judge had the power to try persons he had indicted and persons he had cited for contempt of the one-man grand jury, there was a serious separation-of-powers problem. See Gallagher, supra; Scigliano, Inquisitorial Proceedings and Separation of Functions: The Case of the Michigan One-Man Grand Jury, 38 U. DET. L. REv. 82, 86-89 (1960); Younger, The Grand Jury Under Attack, 46 J. CRIM. L., C. \& P.S. 26, 223 (1955). This problem was recognized by the Michigan legislature, which enacted a requirement that contempt of a one-man grand jury should be tried before a judge other than the judge who had cited the defendant. MICH. STAT. ANN. \$28.944 (1954). Subsequently, a Michigan court ruled the statute unconstitutional since it deprived the court of its "inherent right" to cite for contempt. On appeal, the United States Supreme Court held that defendant was denied a fair trial when he was tried for contempt by the same judge who had conducted the secret proceedings of the one-man grand jury which gave rise to the contempt citation. In re Murchison, 349 U.S. 133 (1955).

20 See Scigliano, supra note 6, at 313. 
holding unconstitutional a New York statute giving the governor power to appoint a judge to investigate charges of municipal corruption, thenJudge Cardozo noted that "centuries of common-law tradition warn us with echoing impressiveness that this is not a judge's work." ${ }^{21}$

Thus, the grand jury is the most effective check on government corruption. Because of its reputation for political impartiality, it may equally serve as an instrument to absolve the honest public official.

Statutes in every state grant grand juries the power to investigate. ${ }^{22}$ An investigation is generally initiated by a "special charge" from the presiding judge. In some states, the authority to give the special charge is expressly conferred by statute, ${ }^{23}$ whereas in others, it is implied from the statutory requirement that the judge charge the grand jury with respect to its "duties," 24 among which is the duty to investigate political corruption. ${ }^{25}$

All states have statutes which provide a procedure for organizing grand juries. ${ }^{26}$ The term "organization" refers here to the issuance of a court order to the sheriff to convene a panel of grand jurors and not to the purely ministerial functions of making jury lists, drawing jurors, and summoning them to appear for duty. A grand jury organized according to a statute is a "regular" grand jury. This term at common law was used to distinguish the grand jury regularly returned to the court before the beginning of each term from the grand jury specially organized in the exercise of judicial discretion at some other time. ${ }^{27}$ At present, some states have statutes which authorize the organization of special grand juries in certain circumstances. ${ }^{28}$ The term "special" grand jury will be used here, however, in its common-law sense to denote a grand jury organized through an exercise of judicial discretion not specifically authorized by statute.

For purposes of clarification, the "investigatory" grand jury is not a grand jury separate from the regular and special grand juries. The grand jury's traditional functions have been indictment and investigation, and the terms "regular" and "special" refer not to functions but to the method of organization. Thus, an investigatory grand jury is one which, however organized, is at that time engaged in investigation. The investigatory grand jury does not indict; rather, its conclusions are returned to the court by "presentment," which is a catalogue of the crimes uncovered, the suspected offenders, and the evidence on which the conclusions are based. ${ }^{29}$

21 In the Matter of Richardson, 247 N.Y. 401, 412, 160 N.E. 655, 658 (1928).

22 E.g., Ala. Cone tit. 41, $\$ 200$ (1958); ARk. Stat. ANN. \$§43-907, 43-911 (1947); IDAHo Code ANn. \$ 19-1109 (1947).

23 E.g., Cal. Pen. Code § 914.1; Conn. Gen. Stat. Rev. \$ 5445 (1958).

24 See, e.g., IDamo Code ANN. \$19-1013 (1947); Iowa Code $\$ 770.15$ (1958).

25 See, e.g., IdAHo Code ANN. \$19-1109 (1947); IoWA Code \$771.2 (1958).

26 See, e.g., Cax. Pen. CODE $\$ \S 893-914$; MINn. Stat. $\$ \$ 628.42-.56$ (1962); PA. Stat. Ans. tit. 17, $\S \$ 917-83$ (1936).

27 See Commonwealth v. Burton, 31 Va. 645, 647 (1832); THompson \& Merrian, The Organization, Custody and Conduct of JurJes $\$ 497$, at 581 (1882); 4 Wharton, Criminal Law and Procedure \$ 1697, at 440-42 (Anderson ed. 1957). 28 E.g., ARK. Stat. § 43-934 (1947); Idaeo Code ANn. §19-1015 (1947).

29 See generally Kuh, supra note 3. See also Ford, The Grand Jury, 8 L. Soc'y J. 205,211 (1938). 
The presentment is then turned over to the prosecutor, who draws up an information, or to the succeeding grand jury, which reconsiders the evidence in terms of possible indictment. ${ }^{30}$

Ordinarily, a grand jury investigation is conducted by the regular grand jury. On occasion, however, the regular grand jury, particularly in the large metropolitan areas, may be preoccupied in returning indictments against alleged felons; ${ }^{31}$ and even where the information is used, the grand jury may already be involved in an intensive investigation of some other matter and therefore unavailable for a second investigation. If the state legislature has failed to authorize the calling of a special investigating grand jury in such situations when a special charge to the regular grand jury would not be feasible, a judge may in time be confronted with a demand and an attendant need for immediate investigation which he would be powerless under the statute to meet. The power and the propriety of then organizing a special grand jury will be the subject matter of this Note.

\section{The Power To Organize a Special Grand Jury}

\section{A. Development of the Grand Jury as an "Arm of the Court"}

At the time of the Norman invasion of England, there was in each hundred a body of local citizens whose duty it was to inform the government of crimes and suspected offenders. ${ }^{32}$ This Saxon custom continued until the Assize of Clarendon in 1166 decreed that the sheriff-the chief executive officer of the county-should select twelve knights to appear in an accusatorial capacity before the itinerant justice of the royal court at the

30 The "presentment" should be distinguished from the "report," which is an informal accusation directed at general conditions or a specific individual and from which no indictment is framed. The majority of courts will expunge the "report" if it does not pertain to an indictable offense. When political corruption has been involved, however, a few states, emphasizing that unique facts existed which prevented indictment-for example, that the statute of limitations had run or probable cause could not be established because of reluctant witnesses-have permitted the grand jury to expose reprehensible conduct which was not subject to punishment. See Owens v. State, 59 So. 2d 254 (Fla. 1952); In re Report of Grand Jury, 152 Fla. 154, 11 So. 2d 316 (1943); In the Matter of the Presentment by Camden County Grand Jury, 10 N.J. 23, 89 A.2d 416 (1952). See generally Kuh, supra note 3; Van Voorhis, Note on the History in New York State of the Powers of Grand Juries, 16 AlBainy L. Rev. 1 (1962); Note, The Propriety of the Grand Jury Report, 34 TeXAs L. REv. 746 (1956).

31 See Chamberlin, Special Grand Juries in Illinois, 22 J. CRIM. L. \& CRrMrnorogx 163,165 (1931). See also Smith v. Gallagher, $408 \mathrm{~Pa}$. 551, 633-34, 185 A.2d 135, 175-76 (1962) (dissenting opinion). In 1930, the grand juries in Chicago returned an average of 457 indictments per month, spending an average of 15 minutes on each indictment. Chamberlin, supra at 165 . In 1961, the regular monthly grand jury in Philadelphia considered an average of 1,828 bills of indictment. Smith v. Gallagher, supra at 633, 185 A.2d at 175 . Assuming that the grand jury works seven hours per day for 22 days in a given month, it spends an average of five minutes on each indictment. However, many states have replaced indictment with the criminal information. See Morse, supra note 10, at 123.

32 See EDWARDs, op. cit. supra note 7, at 5; Glaser, The Political and Historical Development of the Grand Jury, 8 I. Soc'y J. 192, 195 (1938). 
beginning of each court term. ${ }^{33}$ The change was intended to increase the power of the crown by centralizing criminal administration in the hands of the sheriff, the king's delegate. ${ }^{34}$ This progenitor of the modern grand jury was essentially an executive body performing an executive function as public prosecutor. ${ }^{35}$ Apparently its only investigative function was to identify the persons who had committed the crimes in question; the procedure was more closely akin, therefore, to a modern grand jury's passing upon a particular indictment than to a sweeping investigation of official misconduct. In 1272, however, the grand jury's investigatory powers were considerably broadened by the addition of a duty to inquire generally into the misconduct of public officials, including, significantly, the sheriff himself. $^{36}$ The sheriff's power to organize the grand jury was not derived from statute, and the judiciary performed merely a passive role. ${ }^{37}$

Eventually, the sheriff's power became purely ministerial and was exercised pursuant to a court order to organize the grand jury. ${ }^{38}$ This practice was also not authorized by statute. ${ }^{39}$ Although the grand jury continued to exercise executive functions, its power to return a "no bill" had freed it from executive control, ${ }^{40}$ and it was now primarily responsible to the court which had ordered its organization. Since it could obviate unjustified prosecution by refusing to indict, the grand jury became revered as a protector of individual liberty from executive interference. ${ }^{41}$ Indeed, it was viewed as a counterpoise to the executive and an "arm of the court" whose investigations were fundamentally judicial.

Nevertheless, criminal investigation is normally characterized as an executive rather than a judicial function. When a judge without statutory authorization organizes an investigatory grand jury, it may be thought that

33 See EDwards, op. cit. supra note 7, at 7; Glaser, supra note 32, at 196-97; Kuh, supra note 3 , at 1106 .

34 See Kuh, supra note 3, at 1105 ; Note, supra note 7, at 590.

35 See Glaser, supra note 32, at 201-02.

36 See Edwards, op. cit. supra note 7, at 25; Glaser, supra note 32, at 200-01. See generally Cook, supra note 4, at 47; Kuh, supra note 3, at 1109.

37 See Edwards, op. cit. supra note 7, at 26; Glaser, supra note 32, at 201-02.

38 According to Holdsworth, the change occurred in the thirteenth century as a result of the growth of the justice-of-the-peace system. See 1 HoLnswortr, A HIsTORY OF THE ENGLISE LAW 147-48 (1908). See also Morse, supra note 10, at 115. The sheriff did retain the power to select the members of the panel. This is evidenced by a statute enacted in 1511-12 empowering the judges to alter the membership of the panel to prevent a sheriff from staffing the jury with his own followers. 3 Hen. 8, c. 12. The statute, however, was short-lived. See Glaser, supra note 32, at 203-04. Yet the abuse which it was designed to correct arose again. See Rex v. Shaftesbury, 8 How. St. Tr. 759 (1681), and Trial of Colledge, 8 How. St. Tr. 549 $(1681)$, in which a sheriff who was allied politically with persons accused of treason hand-picked a grand jury which refused to indict. See EDwARDS, op. cit. supra note 7, at 29-30. Today, the matter is regulated in all states by statute. See, e.g., PA. STAT. tit. 17, \&943 (1936).

38 See 1 HoldswortH, op. cit. supra note 38 , at 148.

40 See Glaser, supra note 32, at 202; Note, supra note 7, at 590.

41 See generally Ford, supra note 29, at 206; Kaufman, supra note 7, at 333-34. This view is reflected in the constitutional guarantee of a grand jury. U.S. CoNsT. amend. V. The guarantee applies only to criminal defendants in federal courts; states may abolish the practice of grand jury indictments. Hurtado v. California, 110 U.S. 516 (1884). 
this contravenes the "separation of powers" principle. "Separation of powers" is actually a misnomer since many "powers" are held in common by all three branches, with the power of investigation perhaps the most dramatic. ${ }^{42}$ At the core of those situations which give rise to true "separation of powers" problems is a conflict-of-interest issue, namely, whether the involvement of an official in the decision of a particular matter predisposes him to act in a given way, ${ }^{43}$ or, otherwise stated, whether "a particular combination [of functions] . . . sets the official . . . to working at cross-purposes." 44 For example, one acting both as judge and prosecutor would severely jeopardize the right of a defendant to a fair trial. In contrast, it is questionable whether such a conflict exists when the regular grand jury is unavailable and a judge organizes a special grand jury because he has reason to believe that systematic corruption exists which requires immediate investigation. The rights of those investigated are no more endangered than they would be if the regular grand jury were able to act.

\section{B. Common-Law Organization of Special Grand Juries}

Once grand juries were established as judicial organs, the courts began to organize them without statutory authorization in certain situations when a grand jury was needed but was not otherwise available. Thus, if the sheriff had for some reason failed to return a regular grand jury or had returned one defective in its composition, the courts ordered the organization of a new grand jury upon special venire. ${ }^{45}$ In addition, when crimes were committed or criminals apprehended after the regular grand jury had been discharged, the courts assumed the power to order the impanelling of a new grand jury to return indictments. ${ }^{48}$ Justification for this unauthorized exercise of discretion was found in the jurisdiction of the criminal court to supervise the organization of grand juries.77 Regardless of the validity of this theoretical justification in the light of the history of the grand jury, it is clear that the courts were reasonably attempting to cope with a practical emergency. Since a grand jury indictment was required in order to prosecute for a felony, the accused, absent a specially convened grand jury, would be unjustly detained in jail until the beginning of the next term of court when the regular grand jury could be organized or else the charges against him would be dropped and he would be set free. ${ }^{48}$

42 See generally Scigliano, Inquisitorial Proceedings and Separation of Functions: The Case of the Michigan One-Man Grand Jury, 38 U. DET. L. REv. 82-86 (1960).

43 Id. at 85 .

44 Ibid.

45 See 2 Hale, Pleas of the Crown 156 (1723). See also Commonwealth v. Burton, 31 Va. 645, 646-47 (1832) ; 4 WHARTON, op. cit. supra note 27, at 440.

46 See authorities cited note 45 supra. See also State v. Brautigan, 310 Ill. 472 , 477-78, 142 N.E. 208, 210 (1923) (dictum).

47 See Commonwealth v. Burton, 31 Va. 645, 646-47 (1832); People v. Blumenfeld, 330 I1l. $474,478,161$ N.E. 857,858 (1928) (dictum).

48 Cf. id. at 477,161 N.E. at 858. 
Although two grand juries did exist concurrently in three English counties, ${ }^{49}$ the general practice seems to have been that only one grand jury at a time functioned in each county. ${ }^{50}$ No authority compelled this practice; it seems to have arisen as a matter of tradition.

\section{Present Status of the Iudicial Power To Organize}

The common-law development of discretionary power in the judiciary to organize a special grand jury has set a pattern which modern decisions have consistently followed. Analytically, however, the presence in each state of a statute prescribing a procedure for organizing a grand jury has added a new element which must be considered.

A minority of states accord their grand jury statutes preemptive weight. Any deviation from the statutory procedure with respect to ministerial matters such as jury lists, drawing jurors, and summoning them to appear renders the grand jury functus officio and its indictments void.51 A fortiori, if a judge departs from the statute in ordering the organization of a grand jury in these states, he is deemed to be acting beyond his authority and to lack jurisdiction to make a valid order. ${ }^{52}$ Analyzing these cases in jurisdictional terms seems highly questionable. If a judge, such as a probate judge, who has not been vested with the power to organize a grand jury should order the sheriff to return one, clearly there would be a jurisdictional defect. But if a judge has the power to organize, an error committed in the exercise of that power would hardly seem to be jurisdictional in nature, although it may well be a ground for reversal. ${ }^{53}$

Most state courts take a more liberal view of a judge's failure to comply with the terms of a procedural statute, looking in each case to see if his error resulted in prejudice to the rights of those investigated or indicted. When the judge has jurisdiction to organize and his error is not prejudicial, these courts refuse to invalidate the indictments on the ground that the defect is not so substantial as to warrant the disruption of criminal administration which would follow a declaration of invalidity. ${ }^{54}$ Although

49 See State v. Brautigan, 310 I11. 472, 477, 142 N.E. 208, 210 (1923) (dictum); 1 ChitTy, Criminal Law 310 (3d ed. 1836), quoted in State v. Loveless, 142 W. Va. 809, 818 ,98 S.E.2d 773, 779 (1957) ; 2 HALE, op. cit. supra note 45, at 26.

50 See, e.g., State v. Brautigan, supra note 49 (dictum); Opinion to the Governor, 62 R.I. 200, 4 A.2d 487 (1939) (dictum). See also Chamberlin, supra note 31, at 169.

51 See Scott v. State, 63 Ala. 59 (1879) ; Bruner v. Superior Court, 92 Cal. 239, 248-51, 28 Pac. 341, 344-45 (1891); Gladden v. State, 13 Fla. 623, 626-27 (1871); Finnegan v. State, 57 Ga. 427, 429 (1876) ; State v. Brautigan, 310 Ill. 472, 478, 142 N.E. 208, 210; In the Matter of Frye, 173 Kan. 392, 395, 397, 246 P.2d 313, 316-17 (1952); Portis v. State, 23 Miss. 578 (1852). See generally EDWARDs, op. cit. supra note 7 , at $47-48 ; 4$ WHARTON, op. cit. supra note 27 , at 427 .

62 See authorities cited note 51 supra.

63 See People ex rel. Bonfils v. District Court, 29 Colo. 83, 85-86, 66 Pac. 1068, 1069-70 (1901) (per curiam); Bruner v. Superior Court, 92 Cal. 239, 270, $28 \mathrm{Pac}$ 341, 351 (1891) (dissenting opinion).

54 See Territory v. Chartz, 4 Ariz. 4, 6, 32 Pac. 166, 166-67 (1893) ; Sutton v. State, 163 Ark. 562, 565-66, 260 S.W. 409, 410 (1924); People v. Byrd, 42 Cal. $2 d$ 200, 206, 266 P.2d 505, 508, cert. denied, 348 U.S. 848 (1954); People ex rel. 
these cases in part manifest an impatience with nonprejudicial technicalities asserted in order to quash an indictment, they also recognize a residual power in the judiciary to organize a grand jury which does not in all respects comport with the statutory requirements. This residual power derives from the court's general power to organize grand juries and its role as the traditional administrator of our system of criminal law. .55

Mere error is involved in those cases in which a judge inadvertently fails to adhere to the statutory procedure in organizing a regular grand jury. A different situation arises when a judge consciously exercises his discretion to organize a grand jury which is wholly unauthorized by statute. In the minority jurisdictions in which technical noncompliance vitiates a grand jury, such an exercise of discretion would manifestly be impermissible. ${ }^{56}$ The majority of states, however, do allow a judge certain discretion to organize special, or nonstatutory, grand juries. ${ }^{57}$

The concept of a residual power which was used to justify a refusal to reverse a judge who failed to organize a regular grand jury in strict accordance with the statute has also been used to support the exercise of discretion in organizing a special grand jury. ${ }^{58}$ There has been no attempt to define in terms the outer limits of this discretion; rather, it has been limited by being particularized to those cases in which special grand juries were organized at common law. Thus, as at common law, the majority of jurisdictions permit a judge to order a special grand jury whenever a regular grand jury is not attending the court, either because one was not called, ${ }^{59}$ or because it was discharged before the alleged crime occurred or before the accused was arrested.00 Similarly, the court may vacate an order of discharge and recall the regular grand jury, provided the term of court for which it was originally called has not expired. ${ }^{61}$ It has also been held

Bonfils v. District Court, supra note 53, at 85-86, 66 Pac. at 1069-70; Imboden v. People, 40 Colo. 142, 152-53, 90 Pac. 608, 612-13 (1907); Meiers v. State, 56 Ind. 336, 341 (1877) ; State v. Disbrow, 130 Iowa 19, 21-23, 106 N.W. 263, 263-64 (1906); People v. Morgan, 133 Mich. 550, 95 N.W. 542 (1903); People v. Petrea, 92 N.Y. 128, 143-44 (1883); Shenker v. Harr, $332 \mathrm{~Pa}$ 382, 2 A.2d 298 (1938); State v. Wescott, 194 Wis. 410, 217 N.W. 283 (1928).

55 See authorities cited note 54 supra.

56 See, e.g., State v. Brautigan, 310 I1l. 472, 142 N.E. 208 (1923); In the Matter of Frye, 173 Kan. 392,246 P.2d 313 (1952).

57 See, e.g., People v. Cochrane, 307 Ill. 126, 133, 138 N.E. 291, 294 (1923); People v. Morgan, 133 Mich. 550, 95 N.W. 542 (1903); Shenker v. Harr, 332 Pa. 382, 2 A.2d 298 (1938).

58 See Rowland v. State, 213 Ark. 780, 782-85, 213 S.W.2d 370, 372-73, cert. denied, 336 U.S 918 (1948); People v. Bonelli, 50 Cal. 2d 190, 192-93, 324 P.2d 1, 2 (1958); People v. Cochrane, 307 I11. 126, 133, 178 N.E. 291, 294 (1923); State v. Haines, 18 N.J. 550, 557-59, 115 A.2d 24, 28-29 (1955), rev'd on other grounds, 20 N.J. 438, 120 A.2d 118 (1956).

69 See, e.g., Straughan v. State, 16 Ark. 37 (1855) ; People v. Blumenfeld, 330 I11. 474, 478, 161 N.E. 857,858 (1928).

60 See, e.g., Nichols v. State, 187 Ark. 999, 1001, 63 S.W.2d 655, 656 (1933); Mackey v. People, 2 Colo. 13, 16 (1873); Stone v. People, 3 I11. 326, 332-33 (1840); State v. Disbrow, 130 Iowa 19,21-23, 106 N.W. 263, 263-64 (1906) ; State v. Dusenberry, 112 Mo. 277, 289, 20 S.W. 461, 464 (1892).

61 See, e.g., Lee v. State, 92 Fla. 645, 109 So. 634 (1926) ; People v. McCauley, 256 I11. 504, 100 N.E. 182 (1912). 
that a judge may order a grand jury to continue its work into a succeeding term if this is necessary for the completion of unfinished business. ${ }^{62}$ This discretion has been justified solely on the ground that the court has the power to facilitate the efficient operation of the criminal judicial system. ${ }^{63}$ If a grand jury had to halt its investigation on the last day of the term and hand over its work to a succeeding grand jury, the investigation would be needlessly disrupted, especially if it were a protracted one requiring many change-overs.

Despite the existence of a general power to organize a grand jury when the need is evident and legislative authority is lacking, this power has not been used to organize two grand juries which would operate simultaneously during the same term. Except in scattered cases, a judge's order directing the impanelling of a second grand jury has been quashed on the ground that the judge exceeded his jurisdiction. ${ }^{64}$ And yet, similarly unauthorized orders to organize a special grand jury in the absence of a regular grand jury, to recall a discharged regular grand jury, or to hold over a regular grand jury have been held to be justifiable exercises of judicial discretion and not in excess of jurisdiction. Jurisdiction is not, therefore, a meaningful basis for analysis in this area; in fact, it is misleading, for actually the courts have looked to the common law for historical support for their decisions. Unfortunately, their historical investigations have been limited to a determination of whether individual powers were exercised, and they have not explored the policy reasons underlying a particular exercise of discretion. ${ }^{65}$ Those powers which were exercised by

62 People v. Bonelli, 50 Cal. 2d 190, 192-93, 324 P.2d 1, 2 (1958) ; People v. Cochrane, 307 III. 126, 133, 138 N.E. 291, 294 (1923) ; People v. Kaplan, 56 Mich. 36, 239 N.W. 349 (1931); People v. Stern, 3 N.Y.2d 658, 148 N.E.2d 400, 171 N.Y.S.2d 265 (1958); Shenker v. Harr, $332 \mathrm{~Pa} .382,2$ A.2d 298 (1938). Contra, In the Matter of Frye, 173 Kan. 392, 395, 346 P.2d 313, 316-17 (1952); State v. Davis, 107 N.J.L. 199, 202-03, 152 At1. 782, 783-84 (Sup. Ct. 1930); cf. Finnegan v. State, $57 \mathrm{Ga} .427$ (1876).

63 See, e.g., Shenker v. Harr, supra note 62, at 285-86, 2 A.2d at 299.

64 See O'Brien v. State, 91 Ala. 16, 18, 8 So. 559, 560 (1890); State v. Brautigan, 310 I11. 472, 476-80, 142 N.E. 208, 210-11 (1923) ; State v. Davis, 107 N.J.L. 199, 203, 152 Atl. 782, 783-84 (1930); Smith v. Gallagher, $408 \mathrm{~Pa}$. 551, 185 A.2d 135 (1962) : State v. Jacobs, 6 Tex. 99, 101 (1851); Nichols v. State, 187 Ark. 999, 1001,63 S.W.2d 655, 656 (1933) (dictum); cf. State v. Overstreet, 128 Mo. 470, 472, 31 S.W. 35, 36 (1895) (dictum).

For cases which have permitted concurrent grand juries, see Shenker v. Harr, $332 \mathrm{~Pa} .382,2$ A.2d 298 (1938); State v. Loveless, $142 \mathrm{~W}$. Va. 809, 816-19, 98 S.E.2d 773, 779-80 (1957); The Queen v. McGuire, 34 N.B. 430, 4 Can. Crim. Cas. 12 (1898). It also appears that two grand juries existed simultaneously in two Pennsylvania cases in which this fact was not challenged. See Dauphin County Grand Jury Investigation Proceedings (No. 1), $332 \mathrm{~Pa}$.289, 336; Commonwealth v. Evans, $190 \mathrm{~Pa}$. Super. 179, 154 A.2d 57 (1959), aff'd per curiam, $399 \mathrm{~Pa}$. 387, 160 A.2d 407, cert. denied, 364 U.S. 899 (1960). Several states by statute permit judges to call more than one grand jury. See People v. Manahan, 32 Cal. 68, 72 (1867); People ex rel. Ferrill y. Graydon, 333 III. 429, 435, 164 N.E. 832, 834-35 (1928) (distinguishing the leading case of State v. Brautigan, supra); State v. Haines, 18 N.J. 550, 556-59, 115 A.2d 24, 28-29 (1955) (statute overruled State v. Davis, supra); People v. Stern, 3 N.Y.2d 658, 148 N.E.2d 400, 171 N.Y.S.2d 265 (1958) ; State ex rel. Doerfler v. Price, 101 Ohio St. 50, 128 N.E. 173 (1920). Rhode Island has indicated in a questionable opinion that such a statute would violate its constitution. Opinion to the Governor, 62 R.I. 200, 4 A.2d 487 (1939).

65 See cases cited notes $59-61$ supra. 
common-law courts in England have been characterized as "inherent powers" exercisable by a modern court; when a given exercise of power is not supported by such authority, it has been considered invalid because not within the court's "inherent power," as in the case of an order creating a second grand jury upon special venire when another grand jury is already in existence. ${ }^{68}$

The "inherent" versus "non-inherent" classification is unfortunate. "Inherent power" suggests an undefined, unlimited authority in the court which is naturally viewed with alarm. The existence of such a power inevitably spawns arbitrary attempts to define its limits, and this is precisely what has occurred in the area of a court's power to organize a special grand jury. Instead of exploring the nature of the judicial power and the bases for a reasonable exercise of judicial discretion, courts too often have woodenly confined the power to organize special grand juries to those situations in which it was exercised by pre-Revolutionary English courts. To the extent that the power has been recognized, it exists today in most instances in the same form as in medieval England.

This judicial preoccupation with the common-law history has produced an anomalous situation. In Pennsylvania, for example, it has recently been held that it is beyond the power of a judge to order a special investigating grand jury when the regular grand jury is still in session. ${ }^{67}$ It remains Pennsylvania law, however, that a judge may, as a matter of discretion, "hold over" a regular grand jury to continue an investigation into a succeeding term of court even though such an investigation would be made concurrently with the functioning of the regular grand jury for that term. ${ }^{68}$ This procedure, while eminently sensible, is equally without statutory authority and equally without precedent at common law.

The concept of "inherent power," like that of "jurisdiction," does not lead to a satisfactory analysis. Such an analysis must be based on an examination of the practical problem confronting the court and the alternatives available for an acceptable solution. It must also consider whether the resolution of the problem is properly the function of the judiciary. The common-law courts' assumption of power to organize a special grand jury in the absence of a regularly organized grand jury involved such an analysis. Clearly, authority could have been provided by statute; but absent such legislation, the judiciary, because charged with the general supervision of the administration of criminal justice and capable of acting on an ad hoc basis, was the appropriate body to fill a gap in the system. ${ }^{.9}$

If properly applied, such an analysis would result in a reversal of the "rule" against concurrently operating grand juries. This would be especially significant in large metropolitan areas, where the workload of an

66 See cases cited note 64 supra.

67 Smith v. Gallagher, $408 \mathrm{~Pa}$. 551, 185 A.2d 135 (1962).

68 See Shenker v. Harr, $332 \mathrm{~Pa}$. 382, 2 A.2d 298 (1938); Commonwealth v. Hubbs, $137 \mathrm{~Pa}$. Super. 229, 8 A.2d 611 (1939).

${ }^{69}$ See authorities cited notes 45-48 supra and accompanying text. 
existing grand jury may preclude it from undertaking a new and prolonged investigation, or may delay the investigation until it can no longer be effective, particularly when the prosecutor has refused for political reasons to initiate one on his own motion. If an investigation is necessary, even though no explicit alternative has been provided by statute, a judge who does not respond and organize a second grand jury will have failed to satisfy the statutory duty imposed upon him through the court's investigating "arm," the grand jury, to investigate official misconduct.70 The public may be led, moreover, to suspect that the judge's refusal to direct an investigation stems from political alliance with the prosecutor.

Although the general early English practice was to the contrary, ${ }^{71}$ it is clear that two grand juries did exist simultaneously in three counties. ${ }^{72}$ The reason for these concurrent grand juries is unknown, but a Canadian case $^{73}$ and a recent West Virginia decision ${ }^{74}$ took note of their existence and held that the organization of concurrent grand juries is within the court's discretion. Underlying such decisions is a policy justification identical to that which supported the exercise of those powers which have been regarded as "inherent"-the need to meet emergencies in the functioning of the criminal judicial system. ${ }^{75}$ Considering the relative lack of sophistication of crime in medieval England and the limited popular control over the operation of government, it is questionable whether two grand juries were in fact necessary. Indeed, it is doubtful whether the problem was ever considered by the English courts. To interpret this silence as a "rule" against concurrently operating grand juries is to rely upon what is at best questionable authority and to ignore the substance of the process by which judicial control over the organization of grand juries developed. ${ }^{76}$

The adoption of statutes explicitly expanding the scope of a judge's power to order investigations of corruption could easily obviate the "power" problem. In the absence of such statutes, however, the substitution of a more flexible judicial discretion for the formalistic application of commonlaw rules would seem to be not only more consistent with the common-law history but also the most effective method for protecting the public from corruption when the regular grand jury is unavailable.

70 See authorities cited notes 22-25 supra and accompanying text.

71 See authorities cited note 50 supra.

72 See authorities cited note 49 supra.

73 The Queen v. McGuire, 34 N.B. 430, 4 Can. Crim. Cas. 12 (1898).

74 State v. Loveless, 142 W. Va. 809, 98 S.E.2d 773 (1957).

75 See authorities cited notes $45-48$ supra and accompanying text.

76 Attempts to justify the "rule" on policy grounds have been singularly unpersuasive. It has been argued that a second "investigatory" grand jury would endanger civil rights, see State ex rel. Doerfler v. Price, 101 Ohio St. 50, 59-60, 128 N.E. 173, 176 (1920); Opinion to the Governor, 62 R.I. 200, 208, 4 A.2d 487, 490 (1939), especially in view of the fact that through the grand jury a prosecutor obtains the power to subpoena records and persons. Although such a danger may exist, it seems to have more relevance to the standards which should be met before a petition for a special grand jury is granted. The regular grand jury possesses 


\section{Proposed Limitations on the Exercise of Judicial Discretion}

As a matter of legal or political theory, therefore, there exist no substantial obstacles to the exercise of judicial discretion to organize a special investigating grand jury. The possibility that such power will be abused, however, has in part been responsible for the courts' reluctance to sanction its exercise. Most important is a lingering apprehension that a politically motivated judge will seek to embarrass an opposition regime when in fact there are no reliable grounds to support a suspicion of corruption. ${ }^{77}$ In addition, a major investigation can involve great cost to the taxpayer 78 and considerable disruption of government operations, since records are subpoenaed and officers are called from their jobs to testify. Moreover, the possibility that a court acting through a grand jury will, in effect, become a permanent overseer of executive and legislative performance is repugnant to the concept of representative government. ${ }^{79}$ Nevertheless, the probity of a public official should unquestionably be subject to public surveillance, and it is this need for public knowledge of official misconduct which is the strongest justification for permitting judicial discretion in organizing a special grand jury. Essentially, fear of abuse of this power is caused by the unjustifiable "judicial" investigation and not by an investigation ordered on the basis of substantial charges of corruption. Possible abuse is no reason to deny the existence of the power altogether. Instead, certain conditions should be required before the power can be exercised.

Many states provide by statute that a judge may order a grand jury to investigate certain charges whenever he deems it necessary. ${ }^{80}$ This, of course, places no effective limits on his power. When a judge is to exercise discretion to organize a special, or non-statutory, investigating grand

the same powers of investigation as the special investigating grand jury, and yet it has not been viewed as a danger to civil rights.

It has also been argued that a second grand jury is an unjustifiable expense of public money. See Smith v. Gallagher, 408 Pa. 551, 569, 185 A.2d 135, 144 (1962); Shenker v. Harr, $332 \mathrm{~Pa} .382,383-84,2$ A.2d 298, 299 (1938). One of the purposes of the Michigan "one-man" grand jury was to reduce the costs of investigation. See Scigliano, The Grand Jury, the Information, and the Judicial Inquiry, 38 ORE. L. REV. 303, 311 (1959). However, when it is clear that an "investigatory" grand jury is necessary, it would seem that the expense involved is the price of good government. Furthermore, it is questionable whether the "public" would prefer the successful depletion of public funds by unchecked corruption to the expense of exposing such crime and punishing it. The very weakness of these arguments suggests the need for re-evaluation of the "rule" in light of modern circumstances.

77 See Finley v. State, 61 Ala. 201, 207 (1878); O'Byrnes v. State, 51 Ala. 25, 29 (1874); Bruner v. Superior Court, 92 Cal. 239, 243-44, 28 Pac. 341, 342 (1891). See generally Van Voorhis, supra note 30, at 5-6.

78 To pay for the preliminary expenses of the proposed special grand jury investigation of municipal corruption in Philadelphia in 1962, the Philadelphia City Council appropriated $\$ 112,000$. More was to be provided when needed. See Smith v. Gallagher, $408 \mathrm{~Pa} .551,569,185$ A.2d 135, 144 (1962).

79 See Shenker v. Harr, 332 Pa. 382, 388-89, 2 A.2d 298, 301 (1938), in which the court in dictum stated that a judge who "held over" a grand jury for such a period of time as to render it virtually permanent would be abusing his discretion.

80 See, e.g., Ariz. R. Crim. P. 81 (1956); Cal. Pen. Code $\$ 904$; Conn. Gen. STAT. ANN. \$54-45 (1960). 
jury, that discretion should be subject to more stringent restriction. If the state has provided for grand jury investigations, the judge should utilize existing machinery as far as possible. If for some reason that machinery is inadequate, only then should he consider whether to order a special panel. The substance of the charges made would then become significant. Case law in Pennsylvania requires that before a regular grand jury investigation can be undertaken, the judge must be satisfied on the basis of trustworthy information that a system of crime exists which affects the entire community, that it cannot be uncovered by the usual modes of criminal investigation, and that there is evidence of at least one "cognate" offense. ${ }^{81}$ This standard is uniquely stringent when compared to the standards other states have established for regular grand jury investigations, but is particularly suitable for cases in which a judge is asked to order an investigation for which no statutory authority can be found. For ordinary crime, the detection processes of the police are generally deemed adequate; when they are not, all states statutorily provide for some form of "judicial" investigation. The special investigating grand jury should be viewed as an additional extraordinary weapon and resorted to only when the situation demands extraordinary action. The social utility of politically impartial "judicial" investigations would thereby be recognized while the possibility of abuse would be curbed through the imposition of stringent standards.

\section{E. Standing To Petition for a Special Grand Jury}

The local prosecuting attorney ordinarily presents the petition requesting a judge to organize an investigatory grand jury. ${ }^{82}$ Through the grand jury, he can gain access to information which would otherwise be beyond his reach, ${ }^{83}$ since he does not possess the necessary subpoena power. However, standing to petition for an investigation should not be limited to the prosecuting attorney, whose political allegiances may make him reluctant to initiate an investigation of alleged political corruption. As a former Michigan governor and attorney general declared to a state legislative committee:

It is when there is official misconduct, bribery and corruption and vice of a commercialized nature, that local prosecutors and local officials hesitate because of the knowledge that they themselves may be involved. It is not in [their] mind to investigate someone higher. ${ }^{84}$ (1959).

81 See Special Grand Jury Case, 397 Pa. 254, 257-60, 154 A.2d 592, 595-96

82 In Pennsylvania, for example, only three of twenty-two petitions for grand jury investigations have been filed by private citizens, see Hamilton Appeal, 407 $\mathrm{Pa}$. 366, 376-81, 180 A.2d 782, 787-89 (1962) (concurring opinion), to which must be added the petition in Smith v. Gallagher, $408 \mathrm{~Pa}$. 551, 185 A.2d 135 (1962).

83 See Dession \& Cohen, The Inquisitorial Functions of Grand Juries, 41 YaLE L.J. 687, 697 (1932).

84 Statement of Wilbur M. Brucker, in Hearings Before Senate Interim Study Committee, Mich. Legislature, Extra Sess. (1950), quoted in Scigliano, supra note 76, at 309. 
When there is a possibility that crimes of this nature have been committed, involving depletion of the public treasury and the use of public office for personal gain, the need for grand jury investigation is paramount. Failure of the prosecuting attorney to initiate a probe should not automatically preclude all investigative processes. The public interest here seems significant enough to justify granting individual taxpayers standing to petition for an investigation. However, a prosecuting attorney is an elected official, and the granting of such a petition will inevitably reflect upon his integrity. The court, moreover, is being asked to exercise a power unauthorized by statute. Consequently, the petition should not be granted unless the court is convinced that there is a concrete need for an investigation which the prosecuting attorney has failed to recognize, with great weight being given to the prosecuting attorney's testimony that he has investigated the charges and found them groundless.

\section{The Power To Ensure an Effective Investigation}

\section{A. Appointing a Special Prosecutor}

Once the grand jury has been convened, a prosecutor will provide it with legal assistance. ${ }^{85}$ Generally, the local district attorney will act as prosecutor, ${ }^{86}$ since the evidence gathered by the grand jury may be used by the state in prosecuting those ultimately indicted. ${ }^{87}$ His role in directing the investigation is pervasive; he interviews potential witnesses and determines who will testify, conducts the interrogation before the grand jury, and advises on the law and the sufficiency of the evidence. ${ }^{88}$ Because of his position as a lawyer and elected prosecutor, he is normally highly effective and persuasive. ${ }^{89}$ The National Commission on Law Observance and Enforcement has concluded that "the grand jury is seldom better than a rubber stamp of the prosecuting attorney ...." Although a grand

85 See generally Mayers, The American Legal System 127 (1955); Appleton, Special Counsel for Grand Juries, 8 Tre PANEL 1 (No. 5, 1930); Daru, Broadening the Scope of the Grand Jury, 12 THE PANEL 12 (1934); Dession \& Cohen, supra note 83, at 698; Littleton, Official Conduct (Auditing) Grand Juries, 11 THE PANEL 21,30 (1933); Note, The Grand Jury as an Investigatory Body, 74 HARv. L. REv. 590, 597 (1961) ; Note, The Grand Jury-Its Investigatory Powers and Limitations, 37 MrN. L. Rev. 586, 599-602 (1953).

86 See People ex rel. District Attorney v. District Court, 75 Colo. 412, 225 Pac. 829 (1924).

87 Ibid.

88 See U.S. National Comm'n on Law Observance \& Enforcement, Report on Prosecution 124-25 (1931); Dession \& Cohen, supra note 83, at 697-700; Kranitz, The Grand Jury: Past-Present-No Future, 24 Mo. L. REv. 318, 328 (1959); Morse, A Survey of the Grand Jury System, 10 ORE. L. REv. 295, 325-29 (1931); Note, supra note 85 , at 596-97.

89 See authorities cited note 88 supra.

90 U.S. National Comm'N on LAw Observance \& Enforcentent, op. cit. supra note 88 at $124-25$. Although many have argued that a special prosecutor is needed to lessen this control, see authorities cited note 88 supra, Professor Konowitz has suggested the organization of "blue ribbon" grand juries whose members would be more educated than the ordinary juror and thus more familiar with the law and less dependent upon the elected prosecutor. See Konowitz, The Grand Jury as an Investigating Body of Public Officials, 10 ST. JoHN's L. Rev. 219, 230-31 (1936). 
jury may exclude a prosecutor if dissatisfied with his presentation and conduct its investigation without any assistance, its lack of investigative experience and familiarity with the law virtually precludes a meaningful investigation. ${ }^{01}$

Most states by statute authorize the court to appoint a special prosecutor when the regular prosecuting attorney is absent because of death or illness or when he is disqualified because of "interest" in the outcome of the investigation..$^{22}$ Moreover, in most states the attorney general is statutorily authorized to supersede the local prosecutor either at the court's request or on his own motion. ${ }^{93}$ Absent such statutory authority, courts have held that, as a matter of discretion, they could appoint special prosecutors under these same circumstances in the exercise of their "inherent power." 94 Even though the "inherent power" rationale is still subject to the same objections interposed with respect to the organization of special grand juries, ${ }^{95}$ the courts' interest in supervising the proper use of their machinery and protecting the judicial system from political or personal misuse justifies their exercise of extraordinary power. Again, the possibility that a court will abuse this power to remove an elected officer has resulted in judicial reluctance at the appellate level to allow a lower court to appoint a special prosecutor when the elected prosecutor is present and competent, unless there is a sufficient showing of the elected prosecutor's "interest" in the outcome of the investigation..$^{98}$

91 See Dession \& Cohen, supra note 83, at 696-99; Konowitz, supra note 90 , at 231. A striking example can be found in the investigation which led to the New York Extraordinary Grand Jury. The regular grand jury had excluded the district attorney and sought to conduct an investigation without his assistance. Its attempt was futile, and it thereafter requested Governor Lehman to appoint an Extraordinary Grand Jury. Thomas Dewey was appointed as prosecutor and impressive discoveries of corruption were made. See Lindsay, Extraordinary Grand Juries Performing Important Service in Stamping Out Crime Under Leadership of Thomas Dezey, 14 The PANeL 3 (No. 1, 1936); Wilkes, A History Making Grand Jury, 13 The Panel 1 (No. 2, 1935).

92 See, e.g., Cal. Pen. Code § 935 ; Colo. Rev. Stat. Ann. \$ 45-1-7 (1953) ; Fla. Stat. AnN. \$27.16 (1961).

93 See, e.g., Ara. Code tit. 55, §235 (1960); Cal. Pen. Code §936; Pa. Stat. ANN. tit. 71, §297 (1962).

94 See, e.g., People ex rel. Lindsley v. District Court, 29 Colo. 5, 12-17, 66 Pac. 896, 898-99 (1901) (interest); Mitchell v. State, $22 \mathrm{Ga} .211,232$ (1857) (absence); State v. Corcoran, 7 Idaho 220, 61 Pac. 1034 (1900) (interest) ; State v. Gonzales, 26 Tex. 197 (1862) (dictum); State ex rel. Kelly v. Alcorn, 6 Conn. Supp. 210, 214-15 (Super. Ct. 1938) (dictum) (interest) ; King v. State, 43 Fla. 211, 222, 31 So. 254, 257 (1901) (dictum) (absence).

95 See notes 66-68 supra and accompanying text.

98 See Gray v. District Court, 42 Colo. 298, 303, 94 Pac. 287, 288-89 (1908); State ex rel. Spencer v. Criminal Court, 214 Ind. 551, 557, 15 N.E.2d 1020, 1022-23 (1938) ; State v. Brown, $63 \mathrm{Kan} .262,65 \mathrm{Pac} .213$ (1901) ; cf. Seaton v. Polk County, 59 Iowa 626, 13 N.W. 725 (1882). But cf. Taylor v. State, 49 Fla. 69, 75-78, 38 So. 380, 382-3 (1905); Mitchell v. State, $22 \mathrm{Ga}$. 211, 232 (1857); Commonwealth v. Lehman, $309 \mathrm{~Pa}$. 486, 490-93, 164 Atl. 526, 527-28 (1932).

Occasionally, however, it has been presumed that a showing of interest was made in the absence of anything in the record to the contrary. See Williams $v$. State, 188 Ind. 283, 301, 123 N.E. 209, 215 (1919); cf. Davis v. People, 77 Colo. 546, 553, 238 Pac. 25, 28 (1925). 
The courts have been hesitant in finding "interest" when the prosecutor was not one of those being investigated. ${ }^{97}$ The fact that the prosecutor and those allegedly guilty of corruption were politically allied has not generally been considered sufficient to justify appointing a special prosecutor unconnected with the persons in power. ${ }^{98}$ And yet, the realities of political life raise significant doubts that an investigation controlled by a prosecutor who owes his position and salary to those under investigation will be faithfully and vigorously pursued.99 Comparison of the spectacular disclosures of corruption made by the New York Extraordinary Grand Jury with Thomas Dewey as special prosecutor and by the Michigan "one-man" grand juries assisted by special prosecutors ${ }^{100}$ with the results of ordinary grand jury investigations conducted by regular prosecutors underscores this conclusion. ${ }^{101}$ The possibility that public cynicism concerning the political independence of the judiciary may be occasioned by the use of the grand jury process to "whitewash" certain public officials is even more significant in the long run than the possibility that corrupt officials may escape detection and prosecution. Moreover, the same public reaction might well occur even if the district attorney conscientiously directed a grand jury investigation which resulted in the dismissal of the charges as unfounded.

As a safeguarding measure, therefore, the burden should be shifted to the district attorney to come forward with evidence of his fitness to conduct an investigation of his political associates, leaving the risk of nonpersuasion on the petitioner. The district attorney should not only be required to explain his previous failure to act, but also to demonstrate that he is impartial in fact and that his public stature is such that the public's respect for the judiciary will not be impaired if he is permitted to fulfill his statutory function. If the court finds him unsuited for the task, it should exhaust all possible alternatives, including a request to the attorney general to supersede, ${ }^{102}$ before exercising its supervisory power over its own machinery ${ }^{103}$ to disqualify him. The district attorney is a court officer; to the extent that his actions may undermine the public's concept of judicial impartiality, they should be regulated by the court.

97 See Gray v. District Court, supra note 96; State ex rel. Spencer v. Criminal Court, supra note 96; Sayles v. Newton, 82 Mich. 84, 46 N.W. 29 (1890); Smith v. Gallagher, $408 \mathrm{~Pa}$. 551, 583-88, 185 A.2d 135, 151-53 (1962).

98 See authorities cited note 97 supra.

99 See Appleton, supra note 85, at 1; Scigliano, supra note 76, at 309-10.

100 See Scigliano, Inquisitorial Proceedings and Separation of Functions: The Case of the Michigan One-Man Grand Jury, 38 U. DET. L. REv. 82, 86-87 (1960).

101 Compare Wilkes, supra note 91, and Marsh, Michigan's "One Man Grand Jury," 8 J. AM. JUD. Soc'y 121, 123 (1924), with Konowitz, supra note 90, at 223-24.

102 See note 93 supra and accompanying text.

103 See text accompanying notes $94-95$ supra. 


\section{B. Binding the Public Treasury for Expenses Incurred in the Investigation}

Although a court has the power to organize a special grand jury and appoint special prosecutors, the success of the investigation may ultimately depend on whether it has the power to obtain the funds necessary to compensate the special prosecutor, his assistants, investigators, and office staff, and to pay for office facilities. ${ }^{104}$ There is no problem if the state has a statute authorizing funds for such court-appointed officials ${ }^{105}$ or if the regular appropriation made for the court is sufficient to cover these expenses. But if this is not the case, necessary assistance can only be obtained if the court has the power to bind the public treasury for the costs of the investigation.

In cases arising in other contexts, the liability of the public treasury for costs resulting from the exercise of judicial discretion has usually been contingent on the power of the court to rule as it did; ${ }^{108}$ if the order was within the court's authority, the costs have been assumed to be a public charge. ${ }^{107}$ In finding the requisite authority, courts have again resorted to the concept of "inherent power" 108 to justify actions which were necessary for the efficient administration of the criminal judicial system. There are also many cases which in dictum recognize the power to appoint various personnel when the regular procedures are for some reason inadequate and the appointments are "necessary" for efficient administration. ${ }^{109}$

104 In Smith v. Gallagher, $408 \mathrm{~Pa} .551,185$ A.2d 135 (1962), the court noted that the special prosecutor was to be paid a salary of $\$ 20,000$ a year, the special assistant prosecutor was to be paid $\$ 17,500$ a year, that offices had been rented to serve as headquarters for the investigation, and that the staff included attorneys, investigators, detectives, stenographers, and clerks. Id. at 582, $185 \mathrm{~A} .2 \mathrm{~d}$ at 150 . The Philadelphia City Council had appropriated $\$ 112,000$ to meet the expenses of the investigation. Id. at $569,185 \mathrm{~A} .2 \mathrm{~d}$ at 144 . In argument before the trial court, the city solicitor had indicated that this was only to cover preliminary expenses and that the total cost might be a million dollars. Id. at 583, $185 \mathrm{~A} .2 \mathrm{~d}$ at 151 .

105 See Cal. Pen. Code $\$ 936$.

106 See, e.g., Schmelzel v. Board of Comm'rs, 16 Idaho 32, 100 Pac. 106, 107 (1909); State ex rel. Hillis v. Sullivan, 48 Mont. 320 , 137 Pac. 392 (1913); Board of County Comm'rs v. Devine, 72 Nev. 57, 294 P.2d 366 (1956); Committee for Marion County Bar Ass'n v. County of Marion, 162 Ohio St. 345, 123 N.E.2d 521, 522 (1954); Leahey v. Farrell, $362 \mathrm{~Pa} .52,66$ A.2d 577, 578 (1949).

107 See Board of Comm'rs v. Stout, 136 Ind. 53, 35 N.E. 683 (1893) (court order requiring the county to operate the courthouse elevator at certain times, cost to be borne by the county, upheld) ; In re Court Room, 148 Wis. 109, 134 N.W. 490 (1912) (court's refusal to move to inadequate new quarters upheld even though it forced the county to renew its lease on the old courtroom); Merrill У. Phelps, 52 Ariz. 526, 532-33, 84 P.2d 74, 79 (1938) (dictum) (appointment of bailiff by the court); State ex rel. Hillis v. Sullivan, 48 Mont. 320, 330-32, 137 Pac. 392, 396 (1913) (dictum) (appointment of bailiff by the court) ; Stone v. Bell, $35 \mathrm{Nev} .240$, 246-47, 129 Pac. 458, 460 (1913) (dictum) (court-appointed accountant).

108 E.g., Nicholl v. Koster, 157 Cal. 416, 422-24, 108 Pac. 302, 305 (1910); State ex rel. Schneider v. Cunningham, 39 Mont. 165, 166-68, 101 Pac. 962, 963 (1909) (alternative holding); Leahey v. Farrell, $362 \mathrm{~Pa} .52,54-55,66$ A.2d 577, 578 (1949) (dictum).

109 See, e.g., Merrill v. Phelps, 52 Ariz. 526, 535-36, 84 P.2d 74, 79 (1938);

State ex rel. Hillis v. Sullivan, 48 Mont. 320, 328-32, 137 Pac. 392, 395-96 (1913);

Board of County Comm'rs v. Devine, 72 Nev. 57, 60, 294 P.2d 366, 367 (1956); 
Since the appointment of a special prosecutor is considered to be within the "inherent power" of a court, it seems likely that the court can fix his salary and require the county auditor to approve payment. Similarly, since it is considered within the "inherent power" of a court to require the executive to provide adequate facilities for the functioning of the judiciary, ${ }^{110}$ the court could probably order that provision be made for office space at public cost. However, there are cases which hold that even though a court has the "inherent power" to appoint a special prosecutor, the power to appoint investigators, and, presumably, office staff, can only be conferred by statute. ${ }^{111}$ This distinction between appointment of special prosecutors and investigators is yet another result of the inflexible confinement of the "inherent power" doctrine to those precise situations in which the English common-law courts exercised their power.

A grand jury investigation would probably not be significantly impaired by the lack of specially hired investigators or office staff if it were supported by the local law-enforcement authorities. ${ }^{112}$ In view of the cost savings ${ }^{113}$ as well as the propriety of allowing those authorities to perform

Leahey v. Farrell, 362 Pa. 52, 57-58, 66 A.2d 577, 579-80 (1949) ; cf. Fresno County v. Roberson, Martin \& Co., 124 Cal. App. 2d 888, 269 P.2d 252 (Super. Ct. 1954).

For the few cases which actually uphold the validity of the public charge, see Nicholl v. Koster, 157 Cal. 416, 108 Pac. 302 (1910); In re Appointment of the Clerk of the Court of Appeals, 297 S.W.2d 764 (Ky. Ct. App. 1957) (alternative holding); State ex rel. Schneider v. Cunningham, 39 Mont. 165, 173, 101 Pac. 962, 964 (1909) (alternative holding). These cases involved a probation officer, a clerk, and a stenographer, respectively; such .persons differ from special prosecutors in that they are more in the nature of court functionaries. No case was found which involved a challenge to the appointment of a special prosecutor or the organization of a special grand jury on financial grounds. Smith v. Gallagher, $408 \mathrm{~Pa} .551,185$ A.2d 135 (1962), although a taxpayer's suit, was essentially a collateral attack on the validity of the order organizing the grand jury. Presumably, had the order been upheld, the costs would have been considered public charges. It is perhaps significant that none of the challenges to the validity of the appointments of special prosecutors in the cases cited in notes $94,96-97$ supra were based on financial grounds.

110 See, e.g., State ex rel. Kitzmeyer v. Davis, 26 Nev. 373, 68 Pac. 689 (1902); Zangerle v. Court of Common Pleas, 141 Ohio St. 70, 46 N.E.2d 865 (1943); In re Court Room, 148 Wis. 109, 134 N.W. 490 (1912).

111 Allen v. Payne, 1 Cal. 2d 607, 36 P.2d 614 (1934); Woody v. Peairs, 35 Cal. App. 553, 170 Pac. 660 (Dist. Ct. App. 1917). Clearly, the grand jury itself does not have the power to hire investigators, since it is believed that those who finance investigations out of their own pockets will lose the impartiality necessary for a valid grand jury indictment. Burns Int'l Detective Agency v. Doyle, $46 \mathrm{Nev}$. 91, 208 Pac. 427 (1922) (contract was void as against public policy and therefore the agency could not sue the individual members of the grand jury which had employed it) ; People v. Kempley, 265 Pac. 310 (Cal. Dist. Ct. App. 1928), modified, 205 Ca1. 441, 271 Pac. 478 (1928).

112 It has been proposed that a statute be passed authorizing the creation of a permanent special staff in the district attorney's office which would specialize in assisting grand jury investigations. The staff would be composed of skilled investigators appointed by the state on the basis of a civil service examination. The proposal is designed to preclude political influence by making the investigating unit a continuing one divorced from political changes. See Daru, supra note 85, at 12 .

113 The amount of money required may be a significant element in a finding of lack of "necessity" for the appointment. Whenever the "inherent power" of a court was invoked to support a public charge, relatively small amounts of money were almost always involved. In the two cases involving sizable expenditures, Board of Comm'rs v. Gwin, 136 Ind. 562, 36 N.E. 237 (1894) (court order to rebuild the courthouse), and Committee for Marion County Bar Ass'n v. Marion County, 162 Ohio St. 345, 123 N.E.2d 521 (1954) (court order to build an elevator in the 
their designated functions, the court should whenever possible permit them to provide investigative assistance. Nevertheless, collusion between lawenforcement officials and those under investigation should not be allowed to destroy an investigation. It is equally "necessary" to the effective fulfillment of the duty of investigation imposed upon the court's investigating "arm" that the court have the power to appoint investigators and assistants as well as the power to appoint a special prosecutor.

\section{ConcLusion}

Because of its unique investigative powers, the grand jury is potentially the most effective body to which the public can look for exposure of corruption. This potential has not been fully realized because of the inflexible application of common-law "rules" regarding the court's "inherent power." Yet the "rules" themselves are but the products of ad hoc attempts to remedy problems relating to the operation of the criminal judicial system which Parliament had not sought to regulate. Rigid adherence to these practices without reference to their underlying rationales and their applicability to modern circumstances has greatly diminished the utility of grand jury investigations. The problem is appropriately the subject of legislation, and some states, notably California and Michigan, do have statutes governing the power of a court to organize investigatory grand juries ${ }^{114}$ and to replace the district attorney with a politically neutral prosecutor. ${ }^{115}$ Absent such legislation, however, a review of the grand jury's development and the power of the courts to supervise and administer the criminal judicial system indicates that courts do have the power to act in extraordinary situations. To deny this nonstatutory power is to impair effective public control of governmental corruption, thereby undermining public faith in the political impartiality of the judiciary.

\section{David C. Toomey}

courthouse), the courts failed to find the requisite "necessity." These orders were directed toward permanent improvements rather than emergency repairs, and it was on this ground that the court in State ex rel. Finley v. Pfeiffer, 163 Ohio St. 149, 154-55, 126 N.E.2d 57, 60-61 (1955), harmonized Marion Connty with Zangerle v. Court of Common Pleas, 141 Ohio St. 70, 46.N.E.2d 865 (1943), which upheld an order requiring the holder of an office adjacent to the courtroom to vacate so that the court might expand its facilities.

114 See Cal. Pen. Code $\$ \S 904,925$; Mrch. Stat. Ann. $\$ \$ 28.943-945$ (1954). Georgia has approached this problem by giving extraordinary powers to its regular grand juries. See GA. Code ANN. \$\$ 59-309 to -312 (1933).

115 See Cal. Pen. Code \$§ 935-36; Mich. Stat. Ann. \$28.944 (1954). Georgia has not authorized the appointment of special prosecutors; however, it has lessened the prosecutor's control by giving the grand jury power to appoint accountants and other investigators to assist its inquiry. GA. CODE ANN. §59-310 (1933). 